\title{
ISOKINETIC ASSESSMENT OF KNEE FLEXOR/ EXTENSOR MUSCULAR STRENGTH IN ELDERLY WOMEN
}

\author{
Marcos de Amorim Aquino, Luiz Eugênio Garcez Leme, Marco Martins Amatuzzi, \\ Júlia Maria D’Andréa Greve, Antônio Sérgio A.P. Terreri, Félix Ricardo Andrusaitis \\ and Júlio César de Carvalho Nardelli
}

AQUINO M de A et al. - Isokinetic assessment of knee flexor/extensor muscular strength in elderly women. Rev. Hosp. Clín.

Fac. Med. S. Paulo 57(4):131-134, 2002.

OBJECTIVE: To assess knee flexor-extensor muscular strength in elderly women with no previous history of musculoskeletal disorders on the lower limbs using an isokinetic dynamometer, in order to obtain data that could be used as a comparative parameter in the evaluation of elderly women with knee disorders, thus facilitating a better rehabilitation of these patients.

METHODS: Twenty-six volunteers aged 75 to 83 years were studied using a Cybex ${ }^{\circledR} 6000$ isokinetic dynamometer. The chosen angular velocity was $60 \%$, and concentric exercise was used for either flexion or extension. The studied parameters were: peak torque, angle of peak torque, and flexor-extensor torque rate.

RESULTS: There were no differences between dominant (D) and nondominant (ND) knee peak torque values. This was true for both flexor $(\mathrm{D}=42.46 \pm 9.09 \mathrm{Nm} / \mathrm{ND}=40.65 \pm 9.38 \mathrm{Nm})$ and extensor $(\mathrm{D}=76.92 \pm 13.97 \mathrm{Nm} / \mathrm{ND}=77.65 \pm 15.21$ $\mathrm{Nm}$ ) movements. The descriptive statistical analysis of the values obtained for the flexor-extensor peak torque rate and for the angle of occurrence of peak torque was the same for the dominant and nondominant sides.

CONCLUSIONS: The values of peak torque for the contralateral side can be used as a reference during rehabilitation of elderly women with acute disease of the knee, and the angular velocity of $60 \%$ is proper and safe for isokinetic assessment of elderly people.

DESCRIPTORS: Isokinetic. Knee. Torque. Muscular strength. Elderly.

\section{INTRODUCTION}

The elderly population is growing world-wide ${ }^{10}$. This epidemiological reality requires a deeper knowledge of their musculoskeletal systems ${ }^{1}$. Since muscular deficiency is a frequent cause of instability and unbalance, proper muscular assessment is important for preservation of joint stability and for preventing falls and disability ${ }^{6,9}$.

Isokinetic assessment is the most accurate method for evaluation of muscular activity ${ }^{11}$. The measurement is made using a dynamometer with a computerized system that permits arcs of movement at a constant angular velocity that has been determined previously. Isokinetic assessment is used for the assessment of muscular equilibrium and for rehabilitation of injuries ${ }^{7}$. However, there are only a few published studies about isokinetic assess-

From the Study of Movements Laboratory of the Ortopaedics and Traumatology Institute, Hospital das Clínicas, Faculty of Medicine, University of São Paulo. ment for the flexor and extensor muscles of the knee in elderly people ${ }^{1,3}$.

The purposes of this study were: a) to assess the flexor-extensor group of muscles of the knee in elderly women through isokinetic dynamometer; b) to ascertain definitively whether the angular velocity of $60 \%$ s is safe and repeatable for isokinetic assessment in this group of patients; and c) to obtain data that could be used as a comparative parameter in the evaluation of elderly women with disorders of the knee, contributing to better rehabilitation of these patients. 


\section{METHODS}

Twenty-six volunteer women aged 75 years or more with no musculoskeletal disorders in lower limbs were studied. They underwent a computerized isokinetic assessment of the flexor and extensor muscles of the knees using a CYBEX $^{\circledR} 6000$ dynamometer. The study was approved by the local committee, and informed consent was obtained from the volunteers before inclusion.

The medium age was $77.85 \pm 2.81$ years, ranging from 75 to 83 years. Medium weight was $63.96 \pm 10.12 \mathrm{~kg}$, ranging from 48 to $100 \mathrm{~kg}$, and medium height was $1.55 \pm 0.06 \mathrm{~m}$, ranging from 1.44 to $1.66 \mathrm{~m}$. The dominant side, which was considered the preferable one for kicking by the volunteer ${ }^{7}$, was the right side for $88.46 \%$ of the volunteers.

\section{Criteria used for the selection of the volunteers}

The criteria used for the selection of volunteers in this study were: a) age $=$ 75 years b) female; c) sedentary life-style (no more than 1 hour of physical activity/week $)^{2,3}$; d) no history of pain in any knee with limitation of the habitual activities for more than 48 hours during the last 2 years; e) no history of previous musculoskeletal disorders ${ }^{4,14}$; no nervous diseases or previous fractures in the lower limbs ${ }^{5}$; f) no instability in any planes or angular deviations in the knees (varus or valgus larger than 10 degrees) ${ }^{16} ; \mathrm{g}$ ) no use of a pharmacological substance that might affect the mechanism of muscular contraction $^{14}$; h) no previous isokinetic assessment; i) no unbalancing systemic disease, such as cardiac diseases and hypertension.

\section{Protocol used for the isokinetic assessment}

The flexion and extension tests were carried out using an angular velocity of $60 \%$. At least 5 minutes of exercise was performed on a flat mat with a walking speed that was previously determined. In order to limit knee movement, the test was performed with the volunteer sitting, with the belts positioned on the thorax, abdomen, thigh, and above the knee on the side that was being evaluated ${ }^{8}$. The force due to gravity was corrected for by an intrinsic device of the dynamometer ${ }^{5}$. Each volunteer executed 4 valid repetitions for each test. In order to isolate the movements of the knee as much as possible, the volunteers were told not to hold on to the lateral supports during the test ${ }^{11,14}$. The tests were performed bilaterally, always beginning on the dominant side. The following parameters were evaluated: a) peak torque, in their absolute values; b) angle of occurrence of peak torque; and c) flexor-extensor peak torque rate. All the values obtained corresponded to concentric contractions.

Table 1 - Peak torque of the knee at $60 \%$ (Nm).

\begin{tabular}{lcccccc}
\hline Muscles & \multicolumn{2}{c}{ Dominant $\operatorname{side}(\mathrm{n}=26)$} & \multicolumn{3}{c}{ Nondominant $\operatorname{side}(\mathrm{n}=26)$} \\
& aver. & $\min -\max$ & $\mathrm{SD}$ & aver. & $\min -\max$ & $\mathrm{SD}$ \\
\hline Flexor & 42.46 & $28-60$ & 9.09 & 40.65 & $26-58$ & 9.38 \\
Extensor & 76.92 & $58-118$ & 13.97 & 77.65 & $56-127$ & 15.21 \\
\hline
\end{tabular}

SD - Standard Desviation

Table 2 - Angle of peak torque of the knee at $60 \%\left(\left(^{\circ}\right)\right.$.

\begin{tabular}{lcccccc}
\hline Muscles & \multicolumn{2}{c}{ Dominant } & side $(\mathrm{n}=26)$ & \multicolumn{3}{c}{ Nondominant } \\
& aver. & $\min -\max$ & $\mathrm{SD}$ & aver. & min-max & SD \\
\hline Flexor & 31.46 & $20-46$ & 7.23 & 31.54 & $17-47$ & 8.58 \\
Extensor & 56.96 & $42-71$ & 7.55 & 54.31 & $43-76$ & 8
\end{tabular}

SD - Standard Desviation

Table 3 - Flexor-extensor relationship (\%).

\begin{tabular}{|c|c|c|c|c|c|c|}
\hline \multirow[t]{2}{*}{ vELOCITY } & \multicolumn{2}{|c|}{ Dominant side $(n=26)$} & \multicolumn{4}{|c|}{ Nondominant side $(n=26)$} \\
\hline & aver. & $\min -\max$ & SD & aver. & $\min -\max$ & SD \\
\hline $60 \%$ & 55 & $39-75$ & 8.67 & 52.12 & $40-80$ & 9.47 \\
\hline
\end{tabular}

SD - Standard Desviation

\section{Statistical analysis}

The statistical analysis was performed using nonparametric tests. The comparison between the dominant side and the nondominant one was made using the Wilcoxon test. The level of significance used in every comparison was $5 \%(P=0.05 \%)$.

\section{RESULTS}

There were no statistically significant differences between the values of peak torque and the angle of occurrence of peak torque for the dominant and nondominant sides. This was true for both flexor and extensor movements (Tables 1 and 2). The descriptive statistical analysis of the values obtained for the flexor-extensor peak torque rate was the same for the dominant and nondominant sides (Table 3). The values for peak torque corrected for corporal weight that were found in the isokinetic assessment followed the 
same pattern of the absolute values obtained, so the inclusion of these corrected values in the analysis was not necessary.

\section{DISCUSSION}

We were challenged to determine the angular velocity that would be used in our study. We needed to find an angular velocity that would allow us to perform proper evaluation without risking the physical integrity of volunteers. We adopted the angular velocity of $60 \%$, because it is appropriate for the assessment of peak torque in elderly people, and it is one of the safest angular velocities for the patellofemoral joint ${ }^{15}$. In addiction, using this angular velocity would allow us to compare our results with other data in literature ${ }^{12,18}$.

The results showed that there were no statistically significant differences between the values of peak torque and of the angle of occurrence of peak torque for the dominant and nondominant sides. This was true for both flexor and extensor movements. These results were similar to those reported for young women ${ }^{18}$ and are very important, since data in the literature show that peak torque is the best correlated measurement in isometric exercise ${ }^{13}$.
Therefore, the results allow us to use the values of peak torque of the non-affected side as the preferable reference parameter during the rehabilitation of elderly people who have experienced trauma to the knee.

However, it is essential to emphasize that this comparison should not be extended to patients with chronic diseases on the knee. Since these diseases often occur bilaterally, it would be a mistake to assume that an injured contralateral lower limb is a measure of normality. The complaint of pain during isokinetic assessment for patients with patellofemoral disease might result in an inappropriate evaluation of the real functional capacity of these patients, and consequently, in inappropriate rehabilitation programs.

The descriptive statistical analysis of the values obtained for the flexorextensor peak torque rate was the same on the dominant and nondominant sides. The extensor peak torque was almost the double that of the flexor peak torque. These results are similar to those reported in literature ${ }^{12}$.

We had difficulty comparing the results obtained in our study with those in literature, since there are only a few available studies on isokinetic assessment of the flexor and extensor muscles of the knee among elderly people ${ }^{1,3}$. There are even fewer studies on elderly women. The lack of a standard angular velocity for this kind of assessment is a further problem, with evaluations obtained using many different angular velocities, making any comparison between them unfeasible.

The knee joint, due to its anatomical and functional characteristics, is one of the most mechanically overloaded joints and the most unstable one in the musculoskeletal system, which makes it the most susceptible joint to lesions. The older the patient, the higher the frequency of this kind of disorder. For this reason, we point out the need for obtaining data that could be used as a standard parameter for elderly women with disease of the knee, thus allowing for a proper follow-up and a better assessment of the degree of recovery in these patients in order to optimize the rehabilitation programs.

\section{CONCLUSIONS}

We concluded from our study that the values of peak torque for the nonaffected side can be used as a reference during the rehabilitation of elderly women with acute disease of the knee and that the angular velocity of $60 \%$ is proper and safe for isokinetic assessment among elderly people.
AQUINO MA e col. - Avaliação isocinética do torque muscular flexorextensor do joelho em mulheres com idade entre 75-83 anos. Rev. Hosp. Clín. Fac. Med. S. Paulo 57(4):131-134, 2002.

OBJETIVO: Avaliar, isocineticamente, o torque dos músculos flexores e extensores dos joelhos de mulheres idosas sem afecções do sistema músculo-esquelético em membros inferio- res, obtendo dados que possam servir como parâmetro de comparação na avaliação de mulheres idosas portadoras de afecções nos joelhos, colaborando para uma melhor reabilitação dessas pacientes.

CASUÍSTICA E MÉTODOS: Vinte e seis voluntárias foram avaliadas. O estudo foi realizado através de um dinamômetro isocinético marca CYBEX $^{\circledR}$ modelo 6000 na velocidade angular de $60 \%$ s. O tipo do exercício utilizado foi o concêntrico, tanto para a flexão quanto para a extensão do joelho. Os parâmetros avaliados foram o torque máximo, o ângulo de ocorrência do torque máximo e a relação flexão/extensão do torque máximo.

RESULTADOS: Os resultados demonstraram não haver diferenças entre os valores do torque máximo do lado dominante (D) e do lado não dominante (ND). Isto foi verdadeiro tanto para o movimento flexor $(\mathrm{D}=42,46 \pm$ 
9,09 $\mathrm{Nm} / \mathrm{ND}=40,65 \pm 9,38 \mathrm{Nm})$, quanto para o movimento extensor $(\mathrm{D}=76,92 \pm 13,97 \mathrm{Nm} / \mathrm{ND}=77,65 \pm$ 15,21 Nm). Também, a estatística descritiva dos valores encontrados para a relação flexão/extensão do torque máximo e para o ângulo de ocorrência do torque máximo foram semelhantes nos dois lados avaliados.

CONCLUSÕES: Os valores do torque máximo do lado contralateral podem ser usados como referência durante a reabilitação de mulheres idosas portadoras de doença articular agu- da no joelho e a velocidade angular de $60 \%$ é adequada e segura para a avaliação isocinética em idosas.

DESCRITORES: Isocinético. Joelho. Torque. Força muscular. Idoso.

\section{REFERENCES}

1. ANIANSSON A, GRIMBY G \& RUNDGREN A - Isometric and isokinetic quadriceps muscle strength in 70-year-old men and women. Scand J Rehab Med 1980; 12:161-8.

2. BARON R - Normative data for muscle strength in relation to age, knee angle and velocity. Wien Med Wochenschr 1995; 145: 600-6.

3. DAVIES MJ \& DALSKY GP - Normalizing strength for body size differences in older adults. Med Sci Sports Exerc 1997; 29: 713-7.

4. GREVE JMD - Avaliação isocinética dos músculos flexores e extensores do tronco. Análise crítica no diagnóstico funcional das lombalgias crônicas de origem mecânica. São Paulo, 1998 (Tese Livre-Docência - Faculdade de Medicina, Universidade de São Paulo).

5. GROSS MT et al. - Validity of knee flexion and extension peak torque prediction models. Phys Ther 1990; 70:17-22.

6. HUANG $\mathrm{CH}$ et al. - Muscle strength after successful total knee replacement: a 6- to 13- year followup. Clin Orthop 1996; 328: $147-54$.

7. IMAMURA M - Avaliação isocinética dos pés de homens adultos normais. São Paulo, 1994 (Dissertação Mestrado - Faculdade de Medicina, Universidade de São Paulo).

8. IVY JL et al.- Isokinetic contractile properties of the quadriceps with relation to fiber type. Eur J Appl Physiol 1981; 47:24755.

9. KNAPIK JJ et al. - Isokinetic, isometric and isotonic strength relationships. Arch Phys Med Rehabil 1983; 64:77-80.

10.KOPILER DA - Atividade física na terceira idade. Rev Bras Med Esporte 1997; 3:108-12.
11.MOLCZYK L et al. - Reliability of testing the knee extensors and flexors in healthy adult women using a Cybex II isokinetic dynamometer. J Orthop Sports Phys Ther 1991; 14:37-47.

12.NEDER JA et al. - Reference values for concentric knee isokinetic strength and power in non-athletic men and women from 20 to 80 years old. J Orthop Sports Phys Ther 1999; 29:116-126.

13.OSTERNIG LR - Optimal isokinetic loads and velocities producing muscular power in human subjects. Arch Phys Med Rehabil 1975; 56:152-5.

14.PEDRINELLI A - Estudo comparativo da força dos músculos flexores e extensores do joelho pela avaliação isocinética entre pacientes com amputação transtibial e indivíduos normais. São Paulo, 1998 (Tese Doutorado - Faculdade de Medicina, Universidade de São Paulo).

15.PERRIN DH - Isokinetic exercise and assessment. Champaign, Illinois, Human Kinetics Publishers, 1993. p.57-65.

16.REZENDE MU - Estudo das radiografias em estresse na instabilidade do joelho. São Paulo, 1996 (Dissertação Mestrado - Faculdade de Medicina, Universidade de São Paulo).

17.TERRERI ASAP et al. - Isokinetic assessment of the flexor-extensor balance of the knee in athletes with total rupture of the anterior cruciate ligament. Rev Hosp Clín Fac Med S Paulo 1999; 54 (2):35-38.

18.WYATT MP \& EDWARDS AM - Comparison of quadriceps and hamstring torque values during isokinetic exercise. J Orthop Sports Phys Ther 1981; 3:48-56.

Received for publication on June 20, 2001 